\title{
Expertise, politics and public opinion at the crossroads of the European Commission's decision- making: The case of Glyphosate.
}

\section{Giulia Bazzan and Marta Migliorati}

\section{(2) OpenEdition Journals}

Electronic version

URL: http://journals.openedition.org/irpp/849

DOI: $10.4000 /$ irpp. 849

ISSN: 2706-6274

\section{Publisher}

International Public Policy Association

\section{Printed version}

Date of publication: 27 April 2020

Number of pages: $68-89$

ISSN: 2679-3873

\section{Electronic reference}

Giulia Bazzan and Marta Migliorati, «Expertise, politics and public opinion at the crossroads of the European Commission's decision-making: The case of Glyphosate. », International Review of Public Policy [Online], 2:1 | 2020, Online since 01 April 2020, connection on 12 June 2020. URL : http:// journals.openedition.org/irpp/849; DOI : https://doi.org/10.4000/irpp.849

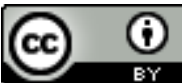

International Review of Public Policy is licensed under a Creative Commons Attribution 4.0 International. 


\section{Expertise, politics and public opinion at the crossroads of the European Commission's decision-making: The case of Glyphosate}

\section{Giulia Bazzan}

Public Administration and Policy Group, Wageningen University, Wageningen, Netherlands.

\section{Marta Migliorati}

Hertie School, Jacques Delors Centre, Berlin, Germany.

\section{Abstract}

With the growing politicisation of European Union (EU) integration, the European Commission is increasingly facing a tension between technocratic and responsive decision-making. How does this tension play out in the process of supranational implementation under comitology rules? We argue that the tension between the Commission's role as a technocrat and as a responsive bureaucrat takes place during the implementation process when the issue at stake becomes politicised. We test our argument through the analysis of the Glyphosate renewal procedure (2015-2017). We process-trace the case by means of semi-structured interviews, media and document analysis. We find that with the increase of issue visibility and subsequent politicisation, the Commission progressively abandons a purely technocratic behaviour. First, it puts in place political strategies such as delays and blame-shifting to release itself from the burden of unpopular decisions. Secondly, it seeks to respond to concerns expressed by consumers by proposing compromise-based measures closer to public interest. Ultimately, we show how the outcome of the policy process is mediated by politicisation and characterised by a shift from technocratic to responsive decision making.

\section{Keywords}

EU Commission, decision-making, comitology, public opinion, politicization, consumer protection, responsiveness 


\section{Introduction}

Among the plethora of existing 'non-majoritarian institutions' (Majone, 1996; Thatcher \& Sweet, 2002) engaging in policy-making and regulation world-wide (Gilardi, 2009; Majone, 1994), the European Commission has received some of the greatest attention in scholarly literature. In fact, its evolving features and role within the European Union (EU) system of governance makes it a particularly interesting object of investigation for several branches of political studies, ranging from organisational approaches to public policy analysis.

While the Commission was largely conceived as a technocratic, elite-driven institution in the early days of EU integration, operating outside the public's eye, an increasing bulk of literature looks at this institution as a 'politicised bureaucracy' (Christiansen, 1997a) facing contrasting demands from the priorities of EU member states on the one hand, and from European citizens on the other. In fact, the originally technocratic institutional design of the EU, functional to the achievement of credible commitments to effective policy outputs (Majone, 2001, 2005; Moravcsik, 1998), has been subjected to growing politicisation (Hooghe \& Marks, 2001, 2009; De Wilde et. al 2016) that has fundamentally challenged insulated, technocratic, decisionmaking. (Haverland et al, 2007, p. 891). This view is corroborated by recent empirical evidence showing that the Commission displays a propensity to be responsive towards public opinion during its policy-making activities (Hartlapp, Metz, \& Rauh, 2014; Haverland, de Ruiter, \& Van de Walle, 2018; Rauh, 2016), by upholding diffuse public interests where the public notes the respective policy choices (Rauh, 2016)

Whereas, under growing politicisation, the tension between technocratic and responsive decision-making by the Commission has been mainly analysed from an agenda-setting standpoint, it has proved harder to observe within the context of supranational implementation, as the latter functions in a highly secretive manner through a system known as "comitology". Moreover, the system applies to very technical areas of policy-making that are expected to be dealt with in a very technocratic and consensual way (Joerges \& Neyer, 1997). Against this background, throughout this article we argue that the tension between the Commission's role as a technocrat and as a political actor also takes place during the process of supranational implementation, when the issue at stake manages to overcome the protected walls of comitology and enter the public arena. In support of our theoretical arguments, we provide a thorough empirical analysis of the development of a recent case of supranational implementation under comitology rules, i.e. the license renewal of the pesticide Glyphosate between 2015 and 2017.

With this study, we aim to contribute to several scholarly debates: first, we add significantly to the literature on EU public policy by offering original empirical evidence for the Commission's responsiveness in the context of supranational implementation. Second, we contribute to the specific field of consumer protection by analysing a highly relevant case in this area. Finally, we enrich the wider discussion about normative and practical implications of non-majoritarian actors' responsiveness in policy-making.

The article is structured as follows: after an overview of the institutional landscape and procedures under which the Commission operates when implementing supranational legislation, we will present our theoretical arguments relating to the Commission's decision-making. We will then present the research design and measurement before testing our framework through process tracing.

In our case we find that with the increase of issue visibility and subsequent politicisation, the Commission progressively abandons purely technocratic behaviour. First, it puts in place po- 
litical strategies such as delays and blame shifting to release itself from the burden of unpopular decisions. Second, it seeks to respond to concerns expressed by consumers by proposing compromise-based measures closer to public interest. Ultimately, we show how the outcome of the policy process is mediated by politicisation and characterised by a shift from technocratic to responsive decision-making.

\section{Mapping the institutional landscape: The Commission's decision-making under comitology}

The dynamics at play in the process of supranational (EU-level) implementation are naturally influenced by the formal procedures and actors involved. Hence, in this section we provide an overview of the system under analysis.

The approval of implementing acts in several areas of EU law relies on 'comitology' procedures. They apply when the Commission has been granted implementing powers in the text of a law, in order to discuss the implementation of measures before they are adopted, so as to ensure that these measures are applicable to the situation in the member states (Groenleer, 2011). Comitology committees are listed among the 'least transparent policy-making processes in the democratic world' (Shapiro, 1997), and are traditionally conceived as means of intergovernmental control of the functions of the Commission (Ballmann, et. al. 2002; Franchino, 2000; Pollack, 2003b; Steunenberg, Schmidtchen, \& Koboldt, 1999). Yet, functionalist approaches have looked at them as channels of expertise, which are detached from political bargaining, and which serve the purpose of efficient problem-solving (Majone, 2005; Scharpf, 1988; Wessels, 1998). On a different note, Dehousse (2003) has showed how comitology committees work as 'transnational bureaucratic networks', upon which the Commission exerts considerable power.In a more recent study (2014), the same author claims that comitology decision-making can be politicised and actually appears to be much more conflictual than it seems (Dehousse, Pasarín, \& Plaza, 2014).

In sum, views on comitology differ and open multiple avenues of interpretation of what kind of power the Commission can exercise within them. Yet, besides the informal and often nonobservable dynamics that may take place, under a legal standpoint, the Commission may have more or less power to decide upon the implementation of laws, according to the rules applying to different comitology procedures. These, in turn, depend on the issue under discussion. In particular, the 'examination procedure' is able to produce three different outcomes, two of which may leave the Commission with considerable room for maneuver. According to this procedure, the Commission proposes a draft measure to the committee. When dealing with particularly technical policy areas, it bases its assessment on the advice of EU decentralised agencies (see for instance Groenleer, 2009; Kelemen, 2005; Migliorati, 2019), that is, 'EU-level public authorities with a legal personality and a certain degree of organisational and financial autonomy that are created by acts of secondary legislation in order to perform clearly specified tasks' (Keleman, 2002). Once the draft proposal is ready, member states' representatives in the committee can either adopt or reject it by qualified majority (55\% of EU countries representing at least $65 \%$ of the total EU population). When they fail to reach the required threshold, however, they have the possibility to deliver a 'no opinion' vote and, if this happens, the same proposal is voted in an 'appeal committee', composed of government ministries. In this case, two alternative scenarios may unfold, as displayed in Figure 1. In the first one, the Commission approves the measure unilaterally. In the second, it seeks the approval of member states by either dropping the proposal, or by proposing modified measures until a qualified majority is reached. 
Figure 1: Steps in the Examination Procedure

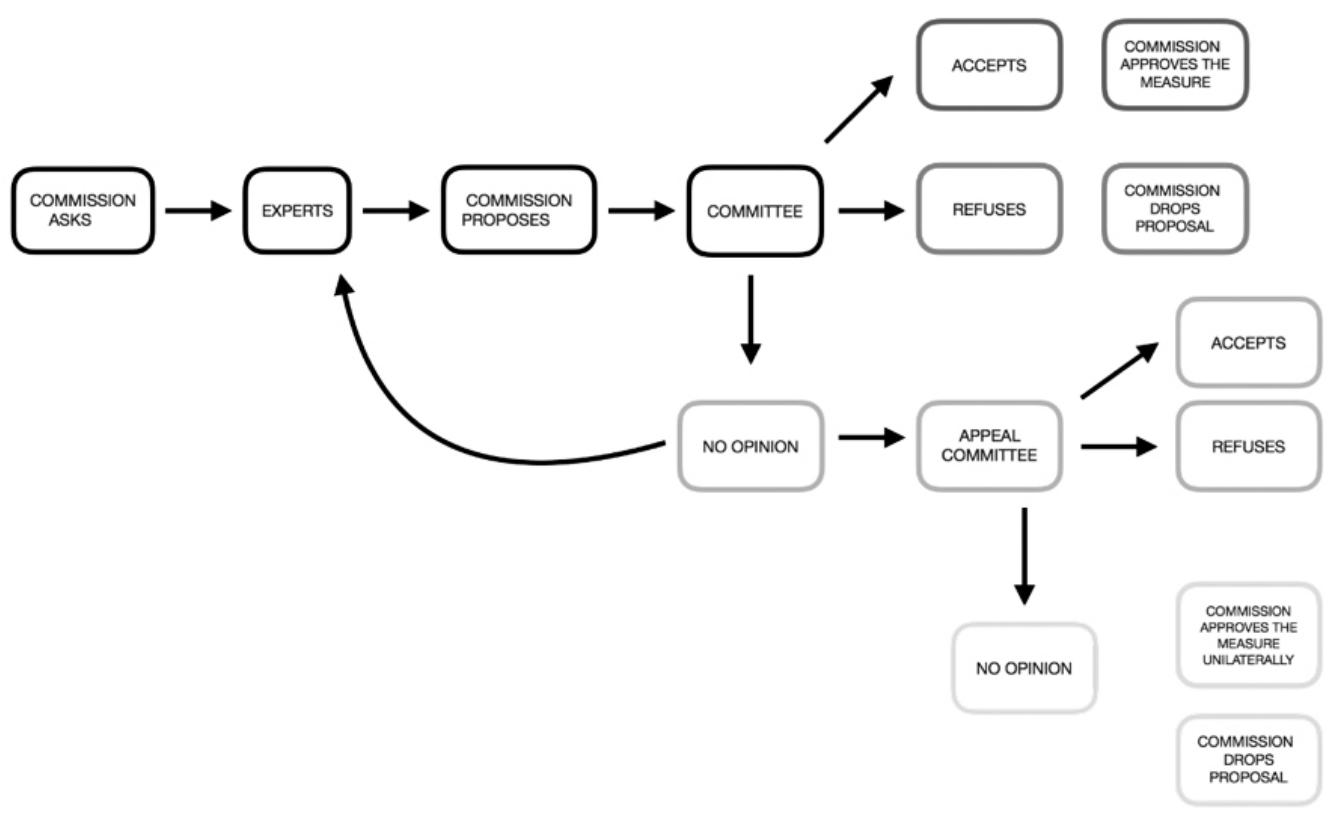

Source: European Commission's Website. Authors' illustration

Empirical evidence (Joerges \& Neyer, 1997; Dehousse et. al 2014) shows that cases of 'no opinion' happen especially in the field of product safety, because these areas are characterised by considerable tension between scientific opinions and policy preferences (Ansell, 2006; Weingart, 1999). The reasons underlying these voting outcomes derive from the uncertainty with regard to the potential adverse effects on public health and the environment of some of these substances, and the consequent resorting to the precautionary principle ${ }^{1}$ of some member states (Tosun, Lelieveldt and Wing, 2019).

Previous empirical work (see Klika et al., 2013) shows that, especially in the context of GMO regulation, states are unable to decide by qualified majority, because they are deeply divided on these matters. Moreover, committee members have rigid negotiating mandates from their government. As a consequence, the responsibility of making decisions often rests on the Commission.

Under the present comitology regime, the Commission has the chance to 'take into account the deeply divided preferences of Member States' (Klika et al. 2013, p. 333). What factors, then, shape the Commission's decision-making in these situations? In the next section, we present our theoretical arguments in this regard.

\section{When technocracy meets politics: The Commission's logics of decision-making}

This section introduces the theoretical arguments in support of our expectations about the Commission's decision-making logics in the process of supranational policy implementation under the above-described comitology rules. Mainly, we claim that, when facing increasingly 
politicised situations, the Commission is torn between its role as a non-majoritarian actor on the one hand, and a responsive one on the other. With this argument, we align with a view of the Commission as a 'politicised bureaucracy' faced with a dilemma between its duty to develop and apply common rules and continuous political pressure for deviation (Christiansen, 1997, p. 77).

First, we posit that in standard policy implementation scenarios, the Commission has a priori no reason not to act according to a technocratic style. The Commission is a non-majoritarian, technocratic actor by definition, which is delegated tasks by member states (Moravcsik 1998; Pollack 2003a; Franchino 2000; Franchino 2007) in order to produce credible and efficient policies, according to evidence-based criteria and scientific knowledge. When the Commission receives tasks from the member states, it is expected to perform them with different degrees of discretion (Franchino 2007) within the boundaries dictated by primary and secondary law. Especially when it is delegated tasks in very complex areas, requiring expertise that its officials do not have, the Commission relies substantially on the advice of EU agencies (Migliorati, 2019). Previous scholarly accounts have stressed how, for example, the European Medicines Agency (EMA) has gained de facto decision-making powers over time, and in most instances the agency's recommendation is simply adopted by the Commission as policy without any further investigation (Sabel \& Zeitlin, 2008). Moreover, although it is difficult to quantify the extent to which the European Food Safety Authority (EFSA) opinions are systematically included by the Commission in the policies it adopts (Groenleer 2009), different scholars suggest that the EFSA actively makes policy instead of simply delivering expertise to the Commission (Boin and colleagues, 2014; Hartley, 2016).

Against this backdrop, we argue that when the Commission has to implement legislation, it relies upon the best expertise available to it, by following technical advice and pursuing evidencebased measures (Schrefler, 2010). The standard decision-making style in the implementation of a supranational measure will be, in sum, based on evidence and largely technocratic.

- H0: In standard policy implementation scenarios, the Commission enacts a technocratic decision-making style, by following technical advice and evidence-based criteria.

Yet, the Commission may find itself in situations in which its reputation, intended as the 'set of symbolic beliefs about the agency's capacity, history, and mission' (Carpenter, 2010:33), is at risk. According to van der Veer \& Haverland (2018), a regulator's reputation is a vital asset to the safeguard of its institutional position. In line with this claim, recent studies suggest that the Commission not only derives its legitimation from the added value it produces for its stakeholders (Majone, 1996; Menon \& Weatherill, 2002), but also responds to public preferences, particularly in the field of consumer policies (Rauh, 2019). The implementation of consumer-related policies is particularly pressing for the Commission, as the primary objective of the General Food Law (Regulation 178/2002) is consumer's and public health protection. Given that the Commission is the most important actor taking risk-management decisions at the EU level, for example to renew a license or to withdraw a dangerous substance, it does bear high political costs for unpopular decisions. Hence, if the Commission is exposed to public scrutiny, it plays a role not only as a technocratic actor, but also as a political one. If an issue debated in comitology comes into the public domain, the Commission has reputational incentives to protect its image by enacting political strategies such as delaying and blame-shifting on the one hand, and by seeking compromise-based solutions in response to concerns raised by consumers on the other. 
We argue, in sum, that reputational concerns in supranational implementation become a reality for the Commission when the issue at stake manages to travel outside the 'protected walls' of comitology. When the issue becomes growingly politicised, namely visible, polarised and an object of public mobilisation (De Wilde 2011; Hutter et al. 2016), the Commission faces growing reputational concerns that, in turn, produce political behaviour and ultimately responsive decision-making.

- H1: When the Commission has to face reputational concerns, it shifts from a technocratic decision-making style to a responsive one.

Table 1 summarises our main hypothesis and the mechanisms underlying it. In the next section, we present our research design.

Table 1: Hypothesised mechanism

\begin{tabular}{|l|l|}
\hline Hypothesis & Mechanisms \\
\hline $\begin{array}{l}\text { H1: When the Commission has to face repu- } \\
\text { tational concerns, it shifts from a technocrat- } \\
\text { ic decision-making style to a responsive one. }\end{array}$ & $\begin{array}{l}\text { During the process of supranational imple- } \\
\text { mentation, issue visibility triggers politicisa- } \\
\text { tion, which, in turn, exposes the Commission } \\
\text { to reputational threats. Therefore, the Com- } \\
\text { mission shifts from a traditional technocratic } \\
\text { decision-making style to a responsive one } \\
\text { by implementing measures closer to diffuse } \\
\text { public interests. }\end{array}$ \\
\hline Visibility & Politicisation \\
\hline
\end{tabular}

\section{Research design}

\section{Method}

Drawing on Klijn and colleagues (2010), we seek to focus on the procedural mechanisms, i.e. the system of actions and interactions, in time and space, between the different actors along the decision-making process in relation to specific outcomes (Kaufmann \& Majone, 1986; Righettini \& Bazzan, 2017: 312). According to Mayntz, mechanisms state how and by which intermediary steps a certain outcome follows from a set of initial conditions (2004: 241). Mechanisms are widely recognised as factors that have specific consequences for specific actors in a decisional network (Barzelay 2007:533). We hence undertake a causal reconstruction of realworld events pointing to the activation of the hypothesised mechanisms (Barzelay, 2007: 528) by means of theory-testing process tracing (Beach \& Pedersen, 2013: 56-60). This is a deductive approach recognised as ideal to grasp the interlocking parts of a mechanism leading from $\mathrm{X}$ to $\mathrm{Y}$. We are aware that this methodology maximises the internal validity of causal inferences, whereas it does not generate any external validity per se, and therefore makes generalisation 
harder (Schimmelfennig, 2015:103). In spite of these limitations, we deem this methodology as the most suitable to detect the critical point at which a mechanism is 'unlocked'-in this case, the mechanisms leading the Commission's decision-making from technocratic to responsive.

\section{Data}

The selected case presents a great advantage in comparison to most comitology procedures, because the salience that the renewal of Glyphosate acquired over time put the decision-making process under the spotlight. A considerable amount of data therefore exists. This includes extensive media coverage, European Parliament debates, publications, open letters and public statements. In order to increase the overall robustness of the study, we triangulated the available empirical information with semi-structured interviews, conducted with actors directly involved in the process. We opted to gather perspectives from several sides of the policy spectrum by including: one legal expert in EU politics and advocacy; one highly-ranked Commission representative; one attaché member of the Committee of Plants Animals, Food and Feed (PAFF); two civil society members directly involved in the case, and a Member of the European Parliament working in the Committee on Agriculture and Rural Development. We were unable to talk with members of the European Food Safety Authority, as they refused to be interviewed to avoid further controversies due to the excessive politicisation of the matter ${ }^{2}$. We did not talk with farmers' organisations and industry representatives, as their unified pro-Glyphosate position emerged clearly from public statements and documents. Table 2 displays a list of interviewees (anonymous), roles, dates, places and durations of the interviews.

Table 2- List of interviewees

\begin{tabular}{|c|c|c|c|}
\hline Interviewee id & Role & Place, Date & Duration \\
\hline Interviewee 1 & $\begin{array}{l}\text { Lawyer (EU policies and ECI } \\
\text { expert) }\end{array}$ & $\begin{array}{l}\text { Phone interview, } \\
20 \text { February } 2018\end{array}$ & 15 minutes \\
\hline Interviewee 2 & $\begin{array}{l}\text { European civil society } \\
\text { member (10-year experience } \\
\text { in agrarian and } \\
\text { environmental justice) }\end{array}$ & $\begin{array}{l}\text { Phone interview, } \\
28 \text { February } 2018\end{array}$ & 30 minutes \\
\hline Interviewee 3 & $\begin{array}{l}\text { European civil society } \\
\text { member (ECI coordinator). }\end{array}$ & $\begin{array}{l}\text { Phone interview, } \\
23 \text { March } 2018\end{array}$ & 30 minutes \\
\hline Interviewee 4 & $\begin{array}{l}\text { European Commission } \\
\text { member, former PAFF } \\
\text { Committee Chair }\end{array}$ & $\begin{array}{l}\text { Phone Interview, } \\
5 \text { April } 2018 .\end{array}$ & \\
\hline Interviewee 5 & $\begin{array}{l}\text { Member of the European } \\
\text { Parliament, Committee on } \\
\text { Agriculture and Rural } \\
\text { Development. }\end{array}$ & $\begin{array}{l}\text { Phone interview, } \\
28 \text { March } 2018\end{array}$ & 30 minutes \\
\hline Interviewee 6 & $\begin{array}{l}\text { PAFF Committee Member } \\
\text { (Agriculture and fisheries } \\
\text { attaché) }\end{array}$ & $\begin{array}{l}\text { Phone Interview, } \\
18 \text { May } 2018\end{array}$ & 30 Minutes \\
\hline
\end{tabular}

2 - Email with EFSA Senior Legal Officer, date: 19 February 2018 
A final methodological remark relates to the impact of the case selection on the generalisability of our findings. Being particularly salient in comparison to most cases of comitology procedures, the representativeness of the case may be reduced and, as a consequence, its generalisability as well. However, we maintain that if the theorised mechanisms find empirical corroboration in this specific case, the same mechanisms could occur during any examination procedure, if the latter is subjected to the same conditions of politicisation. In sum, the peculiarity of the case makes it possible to observe dynamics that may potentially occur, although they often do not. In addition, given the increasing politicisation of EU issues, we cannot exclude that this kind of case will take place more frequently in the future.

\section{Measurement}

In applying process tracing to our single-n case, we detected a series of observable manifestations (i.e. indicators) of our main variables of interest.

Our dependent variable, that is the Commission's decision-making style, varies from technocratic to responsive. If technocratic decision-making is in place, we expect to observe that the Commission proposes measures in line with agencies' opinions and with limited engagement with the public (Schrefler, 2010; Groenleer 2009). In case of public engagement, we expect this to be only limited to evidence/science-based claims (Boswell, 2009). Conversely, if the Commission behaves as a 'responsive bureaucrat' (Rauh, 2016), we expect to observe political behaviour including blame-avoidance strategies, where the Commission tries to avoid or to postpone position-taking (Hartlapp et. al, 2014) and direct public engagement through statements and press releases (Muhlbock and Tosun, 2018). Finally, a policy outcome driven by responsive behaviour would be observable in case the Commission's proposal reinforces the regulatory distribution of rights and risks among producers and consumers, in favour of consumers (Rauh, 2016).

Theoretically, we claim that issue politicisation plays a crucial role in triggering the Commission's behaviour in supranational decision-making. According to previous research, the politicisation of EU integration in general is composed of three dimensions. The first one is salience, i.e. the degree to which European integration is visible and important to citizens. The second is polarisation, intended as the degree to which public opinion diverges. The third is mobilisation, meaning the extent to which the public engages with EU integration-related issues (De Wilde et al. 2016; Rauh 2016: Chapter 2). In the context of our empirical analysis, we look at politicisation along these three dimensions while focusing on one specific issue. Hence, we identify salience as the extent to which our object of investigation is visible in the media and debated in public. When an issue becomes salient, we expect to observe increased visibility through news, media and public debates on the subject at stake. Second, we identify polarisation in high disagreement about the topic under discussion, resulting in conflict among member states and politicians, manifestly diverging preferences, and no opinion votes in comitology. Third, we identify mobilisation in advocacy activities, public protests and the use of instruments of democratic participation such as the European Citizens' Initiative. Table 3 summarises the indicators mentioned above. 
Table 3- Variables and indicators

\begin{tabular}{|c|c|c|}
\hline $\begin{array}{l}\text { Variables (steps in } \\
\text { the causal chain) }\end{array}$ & $\begin{array}{l}\text { Indicator (observable mani- } \\
\text { festations) }\end{array}$ & Literature \\
\hline $\begin{array}{l}\text { Technocratic decision- } \\
\text { making }\end{array}$ & $\begin{array}{l}\text { Evidence-based criteria, no/ } \\
\text { very limited engagement with } \\
\text { the public, reliance on available } \\
\text { expertise, science-based claims }\end{array}$ & $\begin{array}{l}\text { Schrefler, 2010; Groenleer } \\
\text { 2009; Rimkutė \& Haverland, } \\
\text { 2015; Joerges \& Neyer 1997; } \\
\text { Boswell, } 2009\end{array}$ \\
\hline Politicisation & $\begin{array}{l}\text { Salience/Visibility: Media } \\
\text { coverage (newspapers, tv, inter- } \\
\text { net); public debates (politicians, } \\
\text { civil society, sector specific ac- } \\
\text { tors...) } \\
\text { Polarisation: generalised disa- } \\
\text { greement about the topic, inter- } \\
\text { state conflict, no consensus in } \\
\text { comitology, contrasting public } \\
\text { statements by politicians } \\
\text { Mobilisation: Protests, advo- } \\
\text { cacy activities, European Citi- } \\
\text { zens' Initiative) }\end{array}$ & \\
\hline $\begin{array}{l}\text { Responsive decision- } \\
\text { making }\end{array}$ & $\begin{array}{l}\text { The Commission's direct en- } \\
\text { gagement with the public } \\
\text { through public statements and } \\
\text { press releases, delay strategies } \\
\text { (e.g. delaying a vote), blame } \\
\text { avoidance through public state- } \\
\text { ments. The Commission's pro- } \\
\text { posal reinforces the regulatory } \\
\text { distribution of rights and risks } \\
\text { among producers and consum- } \\
\text { ers, in favour of consumers }\end{array}$ & $\begin{array}{l}\text { Muhlbock and Tosun, 2018; } \\
\text { Hartlapp et al., 2014; Rauh } \\
2016\end{array}$ \\
\hline
\end{tabular}

In the next section, we proceed to the empirical reconstruction of the Glyphosate renewal process, followed by an analysis in light of our theoretical expectations.

\section{The Glyphosate renewal process}

\section{Product safety rules in the EU}

The approval of active substances ${ }^{3}$ in the EU explicitly requires the concerted action of the European Commission and one EU agency in particular, the European Food Safety Authority

3 - The active component against pest/plant diseases contained in pesticide products. Glyphosate, the object of our empirical analysis, belongs to this category. 
(EFSA), to implement supranational provisions applicable in the member states' territories. The procedure starts with an application issued by the producer to a designated Rapporteur Member State (RMS), whose competent authority verifies if the application is admissible. Within 12 months from the notification of admissibility, the RMS prepares a draft assessment report (DAR), assessing whether the active substance can be expected to meet the approval criteria. The DAR is then submitted to the Commission and the EFSA. The EFSA then proceeds to peer review and has to adopt, within 120 days, a conclusion on whether the substance can be expected to meet the approval criteria. Within six months of receiving the conclusion, the Commission presents a review report and a draft regulation on approval or non-approval of the active substance. This is when the comitology procedure starts and member states' representatives are asked to either adopt or reject the Commission's draft proposal by qualified majority, following the comitology rules mentioned previously. Figure 2 summarises the approval procedure.

Figure 2- Active Substances Approval Procedure

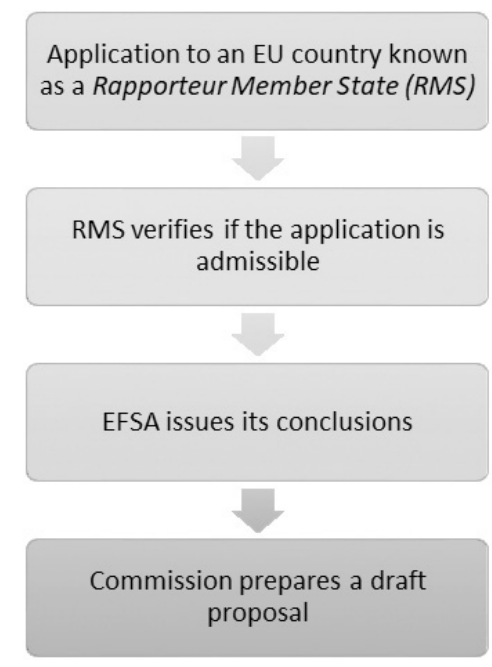

Source: the Authors

\section{T1. A standard renewal procedure}

In 2012, the 15-year license of the active substance Glyphosate was about to expire and required re-approval through the above-described procedure. Hence, several companies, under the name of 'Glyphosate Task Force', notified the Commission about their wish to renew it ${ }^{4}$. The Glyphosate rapporteur's competent authority, the German Bundesinstitut für Risikobewertung (BfR), delivered its first draft report in December $2013^{5}$. At the time, some civil society activists were already interested in Glyphosate because it is usually associated with intensive agriculture and Genetically Modified crops, but the issue was mostly ignored by media outlets and largely unknown to the wider citizenry.

4 - The Glyphosate Task Force published also a position paper on May 2013 to stress its position in favour of the renewal of the substance: http://www.Glyphosate.eu/system/files/mc-files/position_paper_of_the_Glyphosate_task_ force.pdf (accessed: October 2019)

5 - https://www.bfr.bund.de/en/the_bfr_has_finalised_its_draft_report_for_the_re_evaluation_of_Glyphosate188632.html (accessed: October 2019) 


\section{T2. EFSA vs IARC and issue visibility}

While the EFSA was conducting its assessment, on 20 March 2015, the International Agency for Research on Cancer (IARC) published a report stating that Glyphosate was 'probably carcinogenic to humans' (IARC, 2015). The IARC's report served as a catalyst of visibility. Given that Glyphosate, employed by the multinational Monsanto in the preparation of a pesticide known as Roundup ${ }^{\circledR}$ - is the most widely used herbicide across the EU territory, the effect of this assessment had high resonance on worldwide and EU media ${ }^{6}$. The chart in Figure 3 displays Google trends indicating how salience started increasing sensibly exactly from March 2015 onward. This is also shown by news trends ${ }^{7}$, and confirmed by our interviewees (interviews with interviewees 2 and 3 ).

Figure 3- Google trends Glyphosate 2014-2017

Google Trends ‘Glyphosate’ 2014-2017

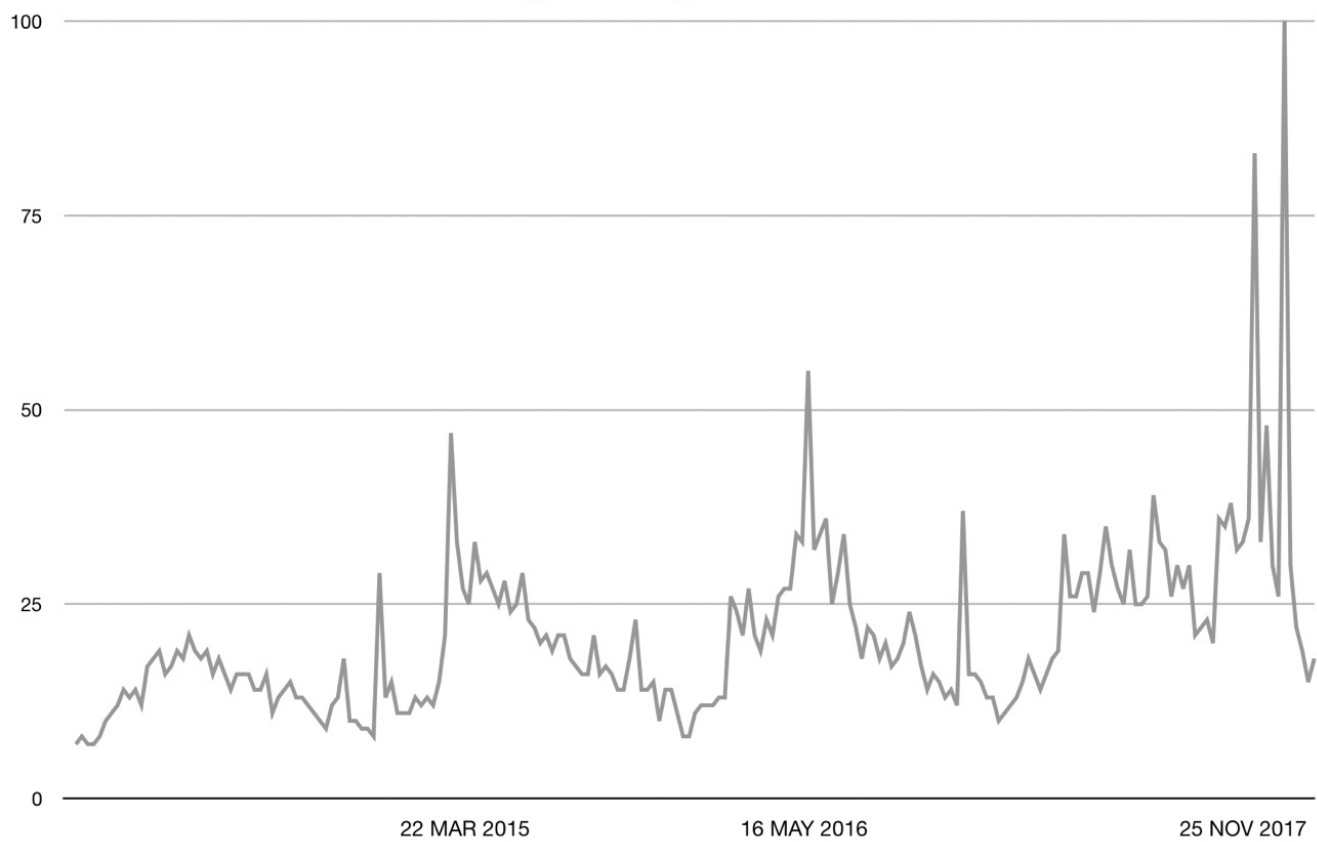

Source: Google Trends

From then onward, the diatribe about the dangerousness of Glyphosate was inserted at the centre of a wider debate about the alleged flaws attributed by civil society to the system of pesticide approval in the EU (interviews with interviewees 2, 3 and 6). The IARC's report therefore signified an ideal opportunity for civil society to make health safety issues connected to pesticide use more visible.

6 - The search for news related to Glyphosate in the period 20 March 2015 - 30 April 2015 on Google news produced a record of over 70 pertinent items from all over the world

7 - The search for news related to Glyphosate in the period 2013-2014 (when the standard renewal process started) on the Euractiv portal produced a record of 1 item (https://www.euractiv.com/?s=Glyphosate\&year=2013\&monthnu $\mathrm{m}=$ \&post_type $=\&$ sections $=$ accessed: October 2019).

The same search in the period 2015-2017 (after IARC's report publication) produced a record of 266 items (https:// www.euractiv.com/?s=Glyphosate\&year=2015\&monthnum=\&post_type=\&sections=accessed: October 2019) 
The Commission initially responded to this escalation in visibility in a largely technocratic way, without releasing public statements, and by simply giving to the EFSA, on 30 April 2015, a further mandate to consider the IARC's publication in its final assessment ${ }^{8}$. For this reason, the EFSA's deadline was extended ${ }^{9}$, and the agency delivered its risk assessment report on 12 November 2015 arguing that 'Glyphosate is unlikely to pose a carcinogenic hazard to humans' (EFSA, 2015). This opinion, which went utterly against the IARC's assessment, met on the one hand an outraged reaction from the scientific community, exemplified by an open letter sent by a scholar, Professor Christopher J. Portier, and co-signed by 95 scientists on November 27, $2015^{10}$. On the other, it was welcomed by farmers' associations and Glyphosate producers ${ }^{11}$, for which the stakes of renewal were very high.

\section{T3. The long road to the first examination procedure}

The license re-approval was pending, at this point, upon a vote in the committee on Plants, Animals, Food and Feed (PAFF). In March 2016, the Commission sought to reapprove the substance for the 15-year period in line with the EFSA's assessment ${ }^{12}$, but Italy, France, Sweden and the Netherlands informally opposed a new 15-year license for Glyphosate. The Commission then postponed the meeting until further notice. Visibility grew stronger in April 2016, when the European Parliament voted, on the first reading, a motion for a non-binding resolution urging the Commission to renew the marketing approval of Glyphosate for just seven years, instead of $15^{13}$. The motion was adopted with 374 votes in favour, 225 against and 102 abstentions $^{14}$. On 19 May 2016, the vote on Glyphosate renewal was once again delayed by the Commission. Indeed, although most member states were in favour of a re-approval (EU Commission, 2016), they would not have obtained the required majority. This time Germany (whose vote is often crucial under QMV, being the largest EU country) announced its intention to abstain due to divisions within the government on the matter, and so did France (De Carbonnel, 2016 $)^{15}$. As the license was due to expire on 30 June 2016, Commissioner Andriukaitis gave a press release on 1st June, wishing a rapid agreement and claiming that the 'ball is now in the Member States' court ${ }^{\prime 16}$ as regards the re-approval.

The first committee vote eventually took place in spite of the controversies (6 June 2016), on a Commission proposal of ten years instead of 15 , in view of compromising with such concerns and securing a swift decision (interview with interviewee 6, Commission Press release 1 June 2016) $)^{17}$. On that day, the committee delivered a 'no opinion' vote, with 20 members in favour,

8 - https://efsa.onlinelibrary.wiley.com/doi/epdf/10.2903/j.efsa.2015.4302

9 - Ref. Ares(2015)3342030 - 11/08/2015 Subject: EFSA peer review of the active substance Glyphosate - Your request for extension of the target date to consider the findings by IARC as regards the potential carcinogenicity 10 - http://www.efsa.europa.eu/sites/default/files/Prof_Portier_letter.pdf (accessed: October 2019)

EFSA replied to Professor Portier's letter on 13 January 2016: http://www.efsa.europa.eu/sites/default/files/EFSA_ response_Prof_Portier.pdf (accessed: October 2019)

11 - http://monsantoblog.eu/the-european-food-safety-authority-Glyphosate-is-unlikely-to-pose-carcinogenichazard-endefrnlesro/\#.VkTOkVNVhBc (accessed: October 2019)

12 - The Guardian, 8 March 2016 (https://www.theguardian.com/environment/2016/mar/08/eu-vote-on-controversial-weedkiller-licence-postponed-Glyphosate accessed: October 2019)

13 - http://www.europarl.europa.eu/doceo/document/TA-8-2016-0119_EN.html (accessed: October 2019)

14 - http://www.europarl.europa.eu/doceo/document/CRE-8-2016-04-13-ITM-012-09_EN.html (accessed: October 2019)

15 - https://www.reuters.com/article/us-health-eu-glyphosate/eu-delays-vote-on-weed-killer-glyphosate-licenceamid-cancer-row-idUSKCNOYA1M1 (accessed: October 2019)

16 - https://europa.eu/rapid/press-release_STATEMENT-16-2011_en.htm (accessed: November 2019)

17 - https://www.euractiv.com/section/agriculture-food/news/commission-says-10-year-glyphosate-extension-is-astarting-point-for-debate (accessed: October 2019) 
one against (Malta) and seven abstentions (Germany, France, Italy, Greece, Austria, Portugal and Luxembourg $)^{18}$. On 24 June 2016, the appeal committee failed to deliver an opinion once again. This time, France joined Malta in its opposition, while Bulgaria joined the abstention side $^{19}$.

\section{T4: The temporary re-approval}

The Commission then had to decide by 30 June 2016 whether to keep Glyphosate on the EU list of approved active substances. Otherwise, after a six-month 'grace period', member states would have been obliged to remove Glyphosate from the market ${ }^{20}$. Eventually, it decided to extend Glyphosate's license for an extra 18 months, pending a further assessment of the substance classification by the European Chemicals Agency (ECHA). On 15 June 2017, the ECHA's Committee for Risk Assessment (RAC) submitted its scientific opinion to the European Commission, concluding that the available scientific evidence did not meet the criteria to classify Glyphosate as a carcinogen (ECHA, 2017) ${ }^{21}$.

\section{T5: Mobilisation: the European Citizens' Initiative and the EFSA under the spotlight}

In spite of the scientific evidence gathered by EU agencies against carcinogenicity, the debate over Glyphosate escalated, and a European Citizens' Initiative (ECI ${ }^{22}$ was launched in January 2017. The ECI asked to ban the herbicide from the internal market and had high resonance in several countries, eventually reaching over one million signatures in July ${ }^{23}$. Controversies reached their peak when, in September 2017, a number of European media outlets published articles questioning the integrity of the EFSA risk assessment of Glyphosate, as the EFSA had allegedly copied and pasted large portions of the dossier from the Monsanto application to BfR (The Guardian, 2017) ${ }^{24}$. The European Parliament's Environment and Agriculture Committee held a public hearing on the 'Monsanto Papers' on 11 October $2017^{25}$ and subsequently called on the Commission to 'adopt necessary measures' to phase out the use of Glyphosate 'no later than 15 December 2022' (European Parliament, 2017) ${ }^{26}$. The day after, the Commission decided not to proceed on a formal committee vote on the ground that committee members were still deeply divided on the matter ${ }^{27}$, and proposed a new text asking for a seven- to five-year renewal (interview with interviewee four).

\section{T6: The third comitology vote and a five-year renewal}

As the grace period was about to expire once again after the ECHA's positive assessment, on 9 November 2017 the third vote on Glyphosate renewal took place. Pressured from different

\footnotetext{
18 - https://ec.europa.eu/transparency/regcomitology/index.cfm?do=search.dossierdetail\&Dos_ID=12899\&dos_ year $=2016 \& d c \_i d=($ accessed: October 2019$)$

19 - https://ec.europa.eu/transparency/regcomitology/index.cfm?do=search.dossierdetail\&Dos_ID=12970\&dos_ year=2016\&dc_id= (accessed: October 2019)starting-point-for-debate (accessed: October 2019)

20 - https://europa.eu/rapid/press-release_MEMO-16-2012_en.htm (accessed: October 2019)

21 - https://echa.europa.eu/-/glyphosate-not-classified-as-a-carcinogen-by-echa (accessed: October 2019)

22 - The ECI is an instrument through which one million EU citizens who are nationals of at least one quarter of the member states can call directly on the European Commission to propose a legal act

23 - https://ec.europa.eu/citizens-initiative/public/initiatives/successful/details/2017/000002 (accessed: October 2019)

24 - https://ec.europa.eu/food/sites/food/files/plant/docs/pesticides_glyphosate_paff_meeting_sum_20171005. pdf (accessed: October 2019)

25 - http://www.europarl.europa.eu/committees/en/agri/events-hearings.html?id=20171009CHE02661 (accessed: October 2019)

26 - http://www.europarl.europa.eu/doceo/document/TA-8-2017-0395_EN.pdf?redirect (accessed: October 2019)

27 - https://euobserver.com/health/139634 (accessed: October 2019)
} 
fronts, including the European Parliament and citizens, the Commission proposed a renewal of five years. The meeting resulted in a no-opinion outcome ${ }^{28}$, and this time the Commission had to face an even stronger opposition than in 2016: Belgium, Greece, France, Croatia, Italy, Cyprus, Luxembourg, Malta, Austria. While Romania, Poland, Germany, Portugal and Bulgaria abstained, and the remaining 14 member states backed the proposal (interview with interviewee 2).

Against all odds, given the impasse, the appeal committee that reconvened on 27 November 2017 eventually approved the renewal of Glyphosate for five years ${ }^{29}$, thanks to Germany's agricultural minister who, unexpectedly and in contrast with his own government's directions, voted in favour of the renewal instead of abstaining ${ }^{30}$.

On 12 December 2017, the Commission finally adopted the license renewal for five years, and published a response to the European Citizens' Initiative ${ }^{31}$, concluding that 'the Commission has no basis to submit the co-legislators a proposal to ban Glyphosate' (European Commission, 2017). It added that, in line with the European Parliament and citizens' demands, the five-year renewal period was 'significantly shorter than the maximum of 15 years foreseen in EU legislation' (European Commission, 2017). Figure 4 summarises the case timeline.

Figure 4- Timeline

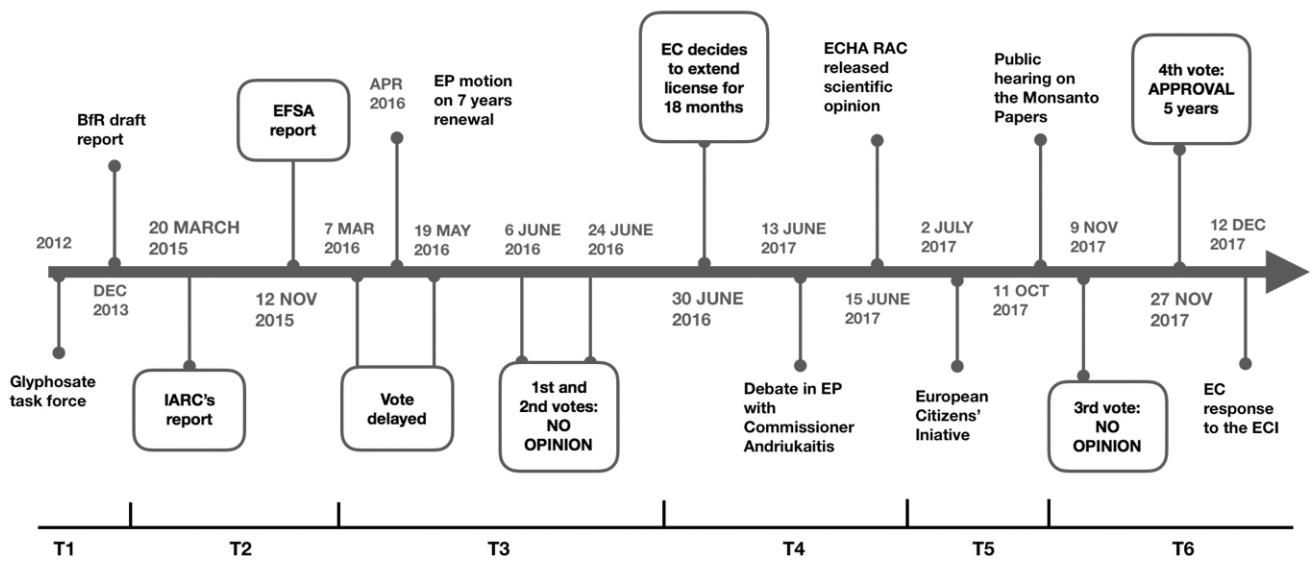

Source : the Authors

\section{Analysis and Discussion}

The case reconstruction depicts a standard comitology decision-making procedure that shifts

28 - https://ec.europa.eu/food/sites/food/files/plant/docs/sc_phyto_20171109_pppl_summary.pdf (accessed:

October 2019)

29 - https://ec.europa.eu/food/sites/food/files/plant/docs/sc_phyto_20171127_pppl_summary.pdf (accessed:

October 2019)

30 - Since the beginning, Germany's line had been to abstain given the divisions between the social democrats (antiGlyphosate) and CDU. When the government crisis started, after the September federal elections, the Agriculture minister Schmidt took the decision "on his own" in spite of Merkel's directions and the veto of the Environment minister Hendriks https://www.sueddeutsche.de/politik/streit-um-unkrautvernichter-minister-schmidt-hat-glyphosatalleingang-monatelang-geplant-1.3769947 (accessed: October 2019)

31 - https://ec.europa.eu/food/sites/food/files/plant/docs/pesticides_glyphosate_eci_final.pdf (accessed: October 2019) 
into an increasingly politicised one. The Commission initially pursued a technocratic decisionmaking style, exemplified by its reliance on technical advice and evidence-based criteria. When the IARC published its report, the Commission's first reaction was to assign the EFSA more time to carry out its assessment, and to avoid delivering public statements or press releases of any kind (T1). However, it progressively had to face multiple concerns, including the European Parliament's call for a license reduction (and later on, license withdrawal), concerns of several member states about the IARC's report, and public mobilisation culminating in the European Citizens' Initiative.

Facing such a thick wall of 'dissensus', the Commission progressively abandoned its technocratic decision-making style in favour of political moves and, eventually, responsive behaviour. First, it put in place delaying and blame-shifting strategies. The reconstruction of the case shows how, after cancelling two votes because it knew that states would not reach the required majority, the Commission's first official proposal was of ten years, and was anticipated by an official statement by the Commissioner in person, claiming that states had the ultimate responsibility on the matter (T3). In absence of a favourable vote in the committee in June 2016 (T4), the Commission faced the first direct threat to its reputation, and the first high tension between the two decision-making logics. Formally, the Commission could have renewed the product's licence at least for the proposed ten-year period. In fact, the EFSA had confirmed its previous assessment about non-carcinogenicity ${ }^{32}$, the examination procedure granted the Commission decision-making power over the matter, and the European Parliament was formally unable to stop any decision in comitology. However, following the EFSA's opinion toutcourt and reapproving the substance for the full period would have damaged the Commission's reputation as a consumer protector by going against civil society and European Parliament demands. Further, to ban it would have meant applying the precautionary principle excessively strictly, by putting the IARC's assessment before EU agencies' and challenging the reputation of its own experts. Hence, between the choice of being entirely technocratic or entirely responsive, the Commission opted to delay the decision until further notice. It renewed the license for just 18 months pending the ECHA's assessment and, eventually, a re-approval in comitology ${ }^{33}$. Alongside this extension, it continued to shift the blame for the renewal upon states (interview with interviewee 6). This emerges from our direct interviews, but also from Mr Juncker's speech about the state of the Union in 2016, stating that 'It is not right that when EU countries cannot decide among themselves whether or not to ban the use of Glyphosate in herbicides, the Commission is forced by Parliament and Council to take a decision. So, we will change those rules - because that is not democracy' (Juncker, 2016, emphasis added) ${ }^{34}$.

The pressures posed by the numerous signatories of the ECI, accompanied by a very vocal European Parliament ${ }^{35}$ (T5), finally (T6) led the Commission to propose a renewal as short as possible (interviews with interviewees two and six), i.e., five years (given that the renewal procedure itself lasts between three and five years). Such a proposal was the result of behaviour that had ceased to follow a technocratic logic. The Commission based its decision neither on agencies' assessment, nor on member states' preferences. Not only, at that point, had multiple assessments by the EFSA and the ECHA corroborated the non-carcinogenicity of the substance, but

\footnotetext{
32 - https://efsa.onlinelibrary.wiley.com/doi/epdf/10.2903/j.efsa.2017.4979 (accessed: October 2019)

33 - https://www.euractiv.com/section/agriculture-food/news/commission-prolongs-glyphosate-licence-by-

18-months/ (accessed: October 2019)

https://ec.europa.eu/food/plant/pesticides/glyphosate/earlier-assessment_en (accessed: October 2019)

34 - https://europa.eu/rapid/press-release_SPEECH-16-3043_en.htm (accessed: October 2019)

35 - http://www.europarl.europa.eu/doceo/document/TA-8-2017-0395_EN.pdf?redirect (accessed: October 2019)
} 
several states were also not in favour of a slim five-year re-approval. All our direct sources confirm that Romania, Poland and Bulgaria did not back the five-year proposal because they did not see any valuable reason not to have a 15- or ten-year renewal, given the positive assessments by the agencies (interviews with interviewees two, three, five, six). Belgium and Austria, on the other hand, had decided to oppose the proposal due to the strong resonance of the European Citizens' Initiative in their countries (interview with interviewee five). Given that Romania, Bulgaria and Poland represent $13 \%$ of EU population, while Belgium and Austria about 3\%, the Commission would have benefited more, if seeking a larger consensus, from sticking to a ten-year proposal instead of proposing five years. In sum, with the escalation of politicisation, the Commission progressively shifted from a technocratic style to a responsive one, in order to secure its reputation vis-à-vis European consumers, represented by civil society organisations and the European Parliament (interview with interviewees one, three and six). Commissioner Andriukaitis in particular, made clear, before the last vote, that the Commission had followed all legal rules, that it simply could not ban the substance even if it wanted to, and that it had no intention of taking any decision without support from the member states ${ }^{36}$ :

I am legally obliged to finalise the situation about Glyphosate, obliged by the law adopted by this very house. We cannot phase out the substance because there is no legal ground to do that. Who will pay fines if I take such a measure? They will go to court, because I am the one legally responsible. What can we do here? For me, it is crystal clear, science-based arguments are on the ground. Some say I am avoiding the precautionary principle - NO! I asked ECHA to assess once again because of the precautionary principle, and now I have no grounds to use it! (Andriukaitis, 2017) ${ }^{37}$

At the end of the process, the Commission did not ban Glyphosate, because there was no legal ground to do it, given agencies' multiple assessments of non-carcinogenicity. Yet, it did propose a ten-year license reduction, which goes in the direction of reinforcing the regulatory distribution of rights and risks in favour of consumers. The Commission was thus able to secure its reputation regardless of the final outcome in the Committee vote: even in case of a unilateral approval, the Commission could have claimed to have done everything in its power to reduce the license to a minimum.

\section{Conclusions}

The Glyphosate license renewal is an example of increasingly politicised disputes about public health and environmental protection on the one hand, and the economic interests of both pesticides' producers and users on the other. During this conflict, an increasing level of public attention was paid to the issue, and a turbulent decision-making process followed. This case shows how such disputes can heavily affect the policy process by modifying not only the preferences of states, but also of non-majoritarian actors such as the Commission.

Hutter and colleagues (2016) argue that if an issue is not debated in public and is not articulated by political organisations, it can only be politicised to a limited extent. In the scenario we described, visibility generated a snowball effect producing politicisation and, eventually, created tension between technocratic decision-making on the one hand and responsive decisionmaking on the other. The process shows, ultimately, how the progressive escalation of an EU-

36 - https://www.europarl.europa.eu/ep-live/en/committees/video?event=20171113-1900-COMMITTEE-AGRI (accessed: October 2019)

37 - The legal ground mentioned by the Commissioner is true to a certain extent, namely, the Commission can take decisions which are different from what the agency recommends, but only if the Commission explains the reasons in detail. 
level issue from hardly visible to very visible, influenced the Commission in its decision to delay the process, to do everything possible not to take responsibility for a renewal, and to reduce the proposed amount of years of the herbicide's license to the very minimum. The delays and blame-shifting game that the Commission and national governments played with each other, and the Commission's ultimate unwillingness to take an autonomous decision, highlight how issue salience triggers politicisation, which makes the Commission face reputational threats and causes it to shift from technocratic to more responsive decision-making.

Process tracing, therefore, corroborates our main hypothesis, H1: when an issue is severely politicised, this can influence the decision-making style of a non-majoritarian actor, even in the rather obscure EU comitology system. In sum, when expertise, politics and public opinion intertwine, purely 'evidence-based' policy-making is simply not attainable, even though it might be more efficient. Member states' governments, but also the Commission, need to consider diffuse public concerns, carried out by actors (such as citizens and the European Parliament) that are normally overlooked in the process of supranational implementation.

What are the lessons we can draw from this case? First, we may find it instructive from a normative perspective, as politicisation seems to be able to produce responsiveness from different sides of the policy-making spectrum. This, in our view, can enhance the quality of the regulatory outcomes under the principle of openness ${ }^{38}$, which imposes on the EU institutions 'a prescriptive, proactive duty to seek broader participation [...] in order to attain broader democratic objectives' (Alemanno, 2014: 85). While democracy is based on legitimate consensus, free elections and participation, technocracy recognizes expertise as the sole basis of authority and power (Radaelli, 1999). Hence, being responsive may represent a way forward to uphold the legitimacy of non-elected bodies vis-à-vis the citizens. Yet, a shift towards higher responsiveness may produce sub-optimal policy outcomes by hindering bureaucrats' ability to find cooperative policies (Rauh, 2016: Ch. 1).

Second, the ability of the public sphere to enter such a secretive procedure as comitology, thanks to visibility, makes us speculate about whether, under the growing politicisation of EU integration, this might happen again in the future. Third, we find the case highly informative, as it shows how the tension between efficiency and responsiveness plays out in the process of policy implementation. In line with previous findings, the European Commission embodies an actor who has to perform different functions at the same time, and its logics of behaviour are multiple and dictated by efficiency and scientific rigour, but also by reputational concerns. Finally, we ought not to overlook the implications for the specific policy field we are analysing. The area of consumer protection - specifically related to food and agriculture - constitutes a particularly important dimension of public policy, providing a lens into a set of contemporary questions (Ansell and Vogel, 2006: 5) related not only to European integration, but also to the politicisation of risk assessment and regulatory science, and to the phenomenon of agricultural protectionism. Recently, scholarly literature has started investigating how conflicting actor rationalities and the overlap of several regulatory roles undermine the effectiveness and legitimacy of the decision-making and implementation of food and agricultural policies (Thomann, 2018).

This article has sought to contribute to all the debates mentioned above, by analysing a very complex case of supranational implementation in the European Union. Future research might be able to enrich this study through new empirical and theoretical work focusing on bureau-

38 - Art. 15(1) TFEU: "In order to promote good governance and ensure the participation of civil society, the Union's institutions, bodies, offices and agencies shall conduct their work as openly as possible." 
cratic responsiveness in and outside the EU, political mobilisation, politicisation, and how these issues relate to policy learning processes and policy change (Schmidt and Radaelli, 2004; Schmidt, 2008).

\section{Bibliography}

Alemanno, A. (2014). Unpacking the principle of openness in EU law: transparency, participation and democracy. European Law Review, 39, 72-90.

Ansell, C., \& Vogel, D. (Eds.). (2006). What's the beef?: the contested governance of European food safety. Cambridge, MA: MIT Press.

Ballmann, A., Epstein, D., \& O’ Halloran, S. (2002). Delegation, Comitology, and the Separation of Powers in the European Union. International Organization, 56(3), 551-574.

https://doi.org/10.1162/002081802760199881

Barzelay, M. (2007). Learning from Second-Hand Experience: Methodology for ExtrapolationOriented Case Research. Governance, 20(3), 521-543.

https://doi.org/10.1111/j.1468-0491.2007.00369.x

Beach, D., \& Pedersen, R. B. (2013). Process-Tracing Methods: Foundations and Guidelines. Ann Arbor, MI: University of Michigan Press.

Boin, A., Busuioc, M., \& Groenleer, M. (2014). Building European Union capacity to manage transboundary crises: Network or lead-agency model?. Regulation \& Governance, 8(4), 418-436. https://doi.org/10.1111/rego.12035

Boswell, C. (2009). The political uses of expert knowledge: Immigration policy and social research. Cambridge: Cambridge University Press.

https://doi.org/10.1017/CBO9780511581120

Carpenter, D. (2010). Reputation and power. Organizational Image and Pharmaceutical Regulation at the FDA. Princeton, NJ: Princeton University Press.

Christiansen, T. (1997). Tensions of European governance: Politicized bureaucracy and multiple accountability in the European Commission. Journal of European Public Policy, 4(1), 73-90. https://doi.org/10.1080/135017697344244

Dehousse, R. (2003). Comitology: who watches the watchmen?. Journal of European Public Policy, 10(5), 798-813.

https://doi.org/10.1080/1350176032000124096

Dehousse, R., Pasarín, A. F., \& Plaza, J. (2014). How consensual is comitology?. Journal of European Public Policy, 21(6), 842-859.

De Wilde, P. (2011). No polity for old politics? A framework for analyzing the politicization of European integration. Journal of European Integration, 33(5), 559-575.

De Wilde, P., Leupold, A., \& Schmidtke, H. (2016). Introduction: the differentiated politicisation of European governance. West European Politics, 39(1), 3-22.

Franchino, F. (2000). Control of the Commission's Executive Functions: Uncertainty, Conflict and Decision Rules. European Union Politics, 1(1), 63-92.

https://doi.org/10.1177/1465116500001001004 
Franchino, F. (2007). The Powers of the Union: Delegation in the EU. Cambridge: Cambridge University Press.

Gilardi, F. (2009). Delegation in the regulatory state: Independent regulatory agencies in Western Europe. Cheltenham: Edward Elgar Publishing.

Grande, E., \& Hutter, S. (2016). Beyond authority transfer: Explaining the politicisation of Europe. West European Politics, 39(1), 23-43.

https://doi.org/10.1080/01402382.2015.1081504

Groenleer, M. (2009). The autonomy of European Union agencies: A comparative study of institutional development. Utrecht: Eburon.

Groenleer, M. L. P. (2011). Regulatory Governance in the European Union: The Political Struggle Over Committees, Agencies and Networks (SSRN Scholarly Paper No. ID 1878511). Retrieved from Social Science Research Network website: https://papers.ssrn.com/abstract=1878511

Hartlapp, M., Metz, J., \& Rauh, C. (2014). Which Policy for Europe?: Power and Conflict inside the European Commission. Oxford: Oxford University Press.

https://doi.org/10.1093/acprof:oso/9780199688036.001.0001

Hartley, S. (2016). Policy masquerading as science: An examination of non-state actor involvement in European risk assessment policy for genetically modified animals. Journal of European Public Policy, 23(2), 276-295.

https://doi.org/10.1080/13501763.2015.1049196

Haverland, M., de Ruiter, M., \& Van de Walle, S. (2018). Agenda-setting by the European Commission. Seeking public opinion?. Journal of European Public Policy, 25(3), 327-345.

https://doi.org/10.1080/13501763.2016.1249014

Haverland, M. (2007). When the welfare state meets the regulatory state: EU occupational pension policy. Journal of European Public Policy, 14(6), 886-904.

https://doi.org/10.1080/13501760701497899

Hoeglinger, D. (2016). The politicisation of European integration in domestic election campaigns. West European Politics, 39(1), 44-63.

https://doi.org/10.1080/01402382.2015.1081509

Hooghe, L., \& Marks, G. (2001). Multi-level governance and European integration. Lanham, MD: Rowman \& Littlefield.

Hooghe, L., \& Marks, G. (2009). A Postfunctionalist Theory of European Integration: From Permissive Consensus to Constraining Dissensus. British Journal of Political Science, 39(1), 1-23. https://doi.org/10.1017/S0007123408000409

Hutter, S., \& Grande, E. (2014). Politicizing Europe in the National Electoral Arena: A Comparative Analysis of Five West European Countries, 1970-2010. JCMS: Journal of Common Market Studies, 52(5), 1002-1018.

https://doi.org/10.1111/jcms.12133

Hutter, S., Grande, E., \& Kriesi, H. (Eds.). (2016). Politicising Europe: Integration and Mass Politics. Cambridge: Cambridge University Press.

Joerges, C., \& Neyer, J. (1997). Transforming strategic interaction into deliberative problem-solving: European comitology in the foodstuffs sector. Journal of European Public Policy, 4(4), 609-625.

Jr, J. S. L., \& Durant, R. F. (2010). Public Opinion, RiskAssessment, and Biotechnology: Lessons from Attitudes toward Genetically ModifiedFoods in the European Union. Review ofPolicy Research,27(1), 59-76. https://doi.org/10.1111/j.1541-1338.2009.00427.x 
Kaufmann, F.-X., \& Majone, G. (1986). Guidance, control, and evaluation in the public sector: The Bielefeld interdisciplinary project. Berlin: de Gruyter.

Keleman, D. R. (2002). The politics of 'eurocratic' structure and the new European agencies. West European Politics, 25(4), 93-118.

Kelemen, R. D. (2005). The Politics of Eurocracy: Building a New European State? In N. Jackbo and C. Parsons (Eds.), The State of the European Union: With US or Against US? (pp.173-189). New York: Oxford University Press.

Klijn, E.-H., Steijn, B., \& Edelenbos, J. (2010). The impact of network management on outcomes in governance networks. Public Administration, 88(4), 1063-1082.

Klika, C., Kim, J., \& Versluis, E. (2013). Why science cannot tame politics: The new EU comitology rules and the centralised authorisation procedure of GMOs. European Journal of Risk Regulation, 4(3), 327-334.

Leupold, A. (2016). A structural approach to politicisation in the Euro crisis. West European Politics, 39(1), 84-103.

https://doi.org/10.1080/01402382.2015.1081510

Majone, G. (1994). The rise of the regulatory state in Europe. West European Politics, 17(3), 77-101.

Majone, G. (1996). Temporal consistency and policy credibility: Why democracies need non-majoritarian institutions. EUI RSC, 1996/57 Retrieved from Cadmus, European University Institute Research Repository: http://hdl.handle.net/1814/1472

Majone, G. (2001). Two Logics of Delegation: Agency and Fiduciary Relations in EU Governance. European Union Politics, 2(1), 103-122.

https://doi.org/10.1177/1465116501002001005

Majone, G. (2005). Dilemmas of European Integration: The Ambiguities and Pitfalls of Integration by Stealth. Oxford: Oxford University Press.

https://doi.org/10.1093/0199274304.001.0001

Mayntz, R. (2004). Mechanisms in the Analysis of Social Macro-Phenomena. Philosophy of the Social Sciences, 34(2), 237-259.

https://doi.org/10.1177/0048393103262552

Menon, A., \& Weatherill, S. (2002). Legitimacy, accountability, and delegation in the European Union. In A. Arnull \& D. Wincott, Accountability and Legitimacy in the European Union ( pp. 113-132). Oxford: Oxford University Press

Migliorati, M. (2019). Relying on agencies in major European Union legislative measures. West European Politics, 43(1), 159-180.

https://doi.org/10.1080/01402382.2019.1602336

Moravcsik, A. (1998). The Choice for Europe: Social Purpose and State Power from Messina to Maastricht. Ithaca, NY: Cornell University Press.

Mühlböck, M., \& Tosun, J. (2018). Responsiveness to different national interests: Voting behaviour on genetically modified organisms in the council of the European Union. JCMS: Journal of Common Market Studies, 56(2), 385-402.

Pollack, M. A. (2003a). Control Mechanism Or Deliberative Democracy?: Two Images of Comitology. Comparative Political Studies, 36(1-2), 125-155.

https://doi.org/10.1177/0010414002239374 
Pollack, M. A. (2003b). The engines of European integration: Delegation, agency and agenda setting in the EU. Oxford: Oxford University Press.

Radaelli, C. M. (1999). The public policy of the European Union: whither politics of expertise?. Journal of European public policy, 6(5), 757-774.

Rauh, C. (2016). A Responsive Technocracy?: EU Politicisation and the Consumer Policies of the European Commission. Colchester: ECPR Press.

Rauh, C. (2019). EU politicization and policy initiatives of the European Commission: The case of consumer policy. Journal of European Public Policy, 26(3), 344-365. https://doi.org/10.1080/13501763.2018.1453528

Righettini, M. S., \& Bazzan, G. (2017). From Certification to Coordination: Mechanisms for Better Results in European Food Safety Policy. Rivista Italiana Di Politiche Pubbliche, 12(3), 309-332. https://doi.org/10.1483/88191

Rimkute, D., \& Haverland, M. (2015). How does the European Commission use scientific expertise? Results from a survey of scientific members of the Commission's expert committees. Comparative European Politics, 13(4), 430-449.

Sabel, C. F., \& Zeitlin, J. (2008). Learning from Difference: The New Architecture of Experimentalist Governance in the EU. European Law Journal, 14(3), 271-327. https://doi.org/10.1111/j.1468-0386.2008.00415.x

Scharpf, F. W. (1988). The joint-decision trap: lessons from German federalism and European integration. Public administration, 66(3), 239-278.

Schimmelfennig, F. (2015). Efficient process tracing Analyzing the causal mechanisms of European integration. In A. Bennet \& J.T. Checkel (Eds.), Process Tracing: From Metaphor to Analytic Tool (pp. 98-125). Cambridge: Cambridge University Press.

Schmidtke, H. (2016). The differentiated politicisation of European tax governance. West European Politics, 39(1), 64-83. https://doi.org/10.1080/01402382.2015.1081511

Schmidt, V. A. (2008). Discursive institutionalism: The explanatory power of ideas and discourse. Annu. Rev. Polit. Sci., 11, 303-326.

Schmidt, V. A., \& Radaelli, C. M. (2004). Policy change and discourse in Europe: Conceptual and methodological issues. West European Politics, 27(2), 183-210.

Schrefler, L. (2010). The Usage of Scientific Knowledge by Independent Regulatory Agencies. Governance, 23(2), 309-330. https://doi.org/10.1111/j.1468-0491.2010.01481.x

Shapiro, M. (1997). The problems of independent agencies in the United States and the European Union. Journal of European Public Policy, 4(2), 276-277. https://doi.org/10.1080/13501769709696343

Steunenberg, B., Schmidtchen, D., \& Koboldt, C. (1999). Strategic Power in the European Union: Evaluating the Distribution of Power in Policy Games. Journal of Theoretical Politics, 11(3), 339-366. https://doi.org/10.1177/0951692899011003005

Thatcher, M., \& Sweet, A. S. (2002). Theory and Practice of Delegation to Non-Majoritarian Institutions. West European Politics, 25(1), 1-22. https://doi.org/10.1080/713601583

Thomann, E. (2018). Food safety policy: Transnational, hybrid, wicked. In B. Guy Peters (Ed.), Oxford Research Encyclopedia of Politics. Oxford: Oxford University Press. 
Tosun, J., Lelieveldt, H., \& Wing, T. S. (2019). A Case of 'Muddling Through? The Politics of Renewing Glyphosate Authorization in the European Union. Sustainability, 11(2), 1-18.

Van der Veer, R. A., \& Haverland, M. (2018). Bread and butter or bread and circuses? Politicisation and the European Commission in the European Semester. European Union Politics, 19(3), 524-545. https://doi.org/10.1177/1465116518769753

Van Ingelgom, V. (2014). Integrating indifference: A comparative, qualitative and quantitative approach to the legitimacy of European integration. Colchester: ECPR Press.

Weingart, P. (1999). Scientific expertise and political accountability: Paradoxes of science in politics. Science and Public Policy, 26(3), 151-161.

https://doi.org/10.3152/147154399781782437

Wessels, W. (1998). Comitology: fusion in action. Politico-administrative trends in the EU system. Journal of European Public Policy, 5(2), 209-234.

Wilde, P. de, Leupold, A., \& Schmidtke, H. (2016). Introduction: The differentiated politicisation of European governance. West European Politics, 39(1), 3-22.

https://doi.org/10.1080/01402382.2015.1081505

Wilde, P. de, Michailidou, A., \& Trenz, H.-J. (2014). Converging on euroscepticism: Online polity contestation during European Parliament elections. European Journal of Political Research, 53(4), 766-783. https://doi.org/10.1111/1475-6765.12050 